\title{
Effects of excessive energy intake and supplementation with chromium propionate on insulin resistance parameters, milk production, and reproductive outcomes of lactating dairy cows
}

\author{
T. Leiva ${ }^{a}$, R.F. Cooke ${ }^{\text {b,*,1 }}$, A.P. Brandão ${ }^{a}$, A.C. Aboin ${ }^{a}$, J. Ranches ${ }^{a}$, J.L.M. Vasconcelos ${ }^{a, *}$ \\ a São Paulo State University - Department of Animal Production, Botucatu 18168-000, Brazil \\ ${ }^{\mathrm{b}}$ Oregon State University - Eastern Oregon Agricultural Research Center, Burns 97720, USA
}

\section{A R T I C L E I N F O}

\section{Article history:}

Received 8 January 2015

Received in revised form

21 August 2015

Accepted 21 August 2015

Keywords:

Chromium

Dairy cows

Energy intake

Insulin resistance

\begin{abstract}
A B S T R A C T
This experiment compared insulin resistance parameters, milk production, and reproductive outcomes in: (1) lactating dairy cows consuming adequate or excessive energy, and (2) lactating dairy cows consuming excessive energy and receiving or not $\mathrm{Cr}$-propionate supplementation. Seventeen primiparous and multiparous, non-pregnant, lactating Holstein cows (initial days in milk $=76 \pm 2$ ) were assigned on $\mathrm{d}$ 0 to: (1) concentrate intake to meet their requirements of net energy for lactation $\left(N E_{L}\right)$ without $\mathrm{Cr}$ supplementation (MAN; $n=5),(2)$ concentrate intake to exceed their $\mathrm{NE}_{\mathrm{L}}$ requirements without $\mathrm{Cr}$ supplementation ( $\mathrm{HIGH} ; n=6$ ), and ( 3 ) HIGH with $2.5 \mathrm{~g} / \mathrm{d}$ of $\mathrm{Cr}$ propionate (HIGHCR; $n=6$ ). Throughout the experiment ( $\mathrm{d} 0$ to 210 ), cows were offered corn silage for ad libitum consumption, and individually received a corn-based concentrate twice daily. Concentrate intake was formulated to allow diets to provide $100 \%$ of daily $\mathrm{NE}_{\mathrm{L}}$ requirements of $\mathrm{MAN}$, and $160 \%$ of daily $\mathrm{NE}_{\mathrm{L}}$ requirements of $\mathrm{HIGH}$ and HIGHCR cows. Cow BW, BCS, and milk production were recorded weekly. Blood samples were collected weekly, prior to and at 2 and $4 \mathrm{~h}$ after the morning concentrate feeding. Six glucose tolerance tests (GTT) were performed, every $42 \mathrm{~d}$, by infusing cows with $0.5 \mathrm{~g}$ of glucose $/ \mathrm{kg}$ of BW. Follicle aspiration for in vitro embryo production was performed via transvaginal ovum pick-up $2 \mathrm{~d}$ after each GTT. Increase in BCS from d 0 to 210 was greater $(P \leq 0.04)$ in HIGH and HIGHCR vs. MAN. Milk production was similar $(P=0.92)$ between treatments. Within weekly samples, serum non-esterified fatty acids concentration were greater $(P \leq 0.05)$ for MAN vs. HIGH and HIGHCR. Serum insulin concentrations and insulin:glucose ratio were often greater $(P \leq 0.05)$ for $\mathrm{HIGH}$, intermediate for HIGHCR, and lesser for MAN (treatment $\times$ day interaction, $P<0.01$ ). During the GTT, serum insulin concentrations and insulin:glucose ratio were greater $(P \leq 0.05)$ for HIGH compared with HIGHCR and MAN from 10 to 60 min relative to the time of glucose infusion. Proportion of embryo produced per oocyte collected was greater $(P \leq 0.02)$ for MAN vs. HIGH and HIGHCR, and similar $(P=0.59)$ between HIGH and HIGHCR. In conclusion, lactating cows consuming excessive concentrate and $\mathrm{NE}_{\mathrm{L}}$ experienced increased insulin resistance and reduced proportion of embryo produced per oocyte collected compared with cows consuming adequate amounts of energy, whereas $\mathrm{Cr}$-propionate supplementation was effective in alleviating insulin resistance caused by excessive $\mathrm{NE}_{\mathrm{L}}$ intake.
\end{abstract}

(c) 2015 Elsevier B.V. All rights reserved.

\section{Introduction}

Inadequate nutrient intake is known to impair performance and welfare of dairy cattle (Van Saun and Sniffen, 1996). As an example, dairy cows often experience increased insulin resistance during the postpartum period, which is largely due to deficient

\footnotetext{
* Corresponding authors.

E-mail addresses: reinaldo.cooke@oregonstate.edu (R.F. Cooke), vasconcelos@fmvz.unesp.br (J.L.M. Vasconcelos).

${ }^{1}$ Programa de Pós-Graduação em Zootecnia/Faculdade de Medicina Veterinária e Zootecnia, UNESP - Univ. Estadual Paulista, Botucatu 18618-970, SP, Brazil.

energy intake (Pires et al., 2007; Sinclair, 2010). Recently, our research group demonstrated that excessive energy intake also increases insulin resistance in non-lactating dairy cows (Leiva et al., 2014). This syndrome, characterized by persistent hyperinsulinemia, has been negatively associated with milk production, reproduction, and health parameters of dairy cattle (Adamiak et al., 2005; LeBlanc, 2010). However, the impacts of excessive energy intake on insulin resistance and production parameters in lactating dairy cattle are still unknown and warrant investigation, given that excessive energy intake is a common concern among late-lactating dairy cows (Van Saun and Sniffen, 1996).

Chromium is a critical component of the glucose tolerance 
factor and facilitates the action of insulin on body cells (Mertz, 1992) by enhancing auto-amplification of insulin signaling, maintaining the active conformation of insulin receptors, and thus promoting greater glucose uptake (Vincent, 2001). Accordingly, $\mathrm{Cr}$ supplementation has been shown to reduce insulin resistance in periparturient dairy cows under negative energy balance, particularly when an organic source of $\mathrm{Cr}$ is used (Subiyatno et al., 1996; Hayirli et al., 2001). Leiva et al. (2014) also reported that Crpropionate supplementation prevented the increase in insulin resistance caused by excessive energy intake in non-lactating dairy cows. However, no research has yet evaluated this relationship in lactating dairy cows consuming excessive energy. Based on this information, we hypothesized that excessive energy intake increases insulin resistance in lactating dairy cows, and $\mathrm{Cr}$-propionate supplementation is an alternative to alleviate this outcome. Hence, this experiment compared insulin resistance parameters, milk production, and reproductive outcomes in: (1) lactating dairy cows consuming adequate or excessive energy, and (2) lactating dairy cows consuming excessive energy and receiving or not $\mathrm{Cr}$ propionate supplementation.

\section{Materials and methods}

This experiment was conducted at the São Paulo State University - Lageado Experimental Station, located in Botucatu, São Paulo, Brazil. The animals utilized were cared for in accordance with the practices outlined and approved by the São Paulo State University Animal Ethics Committee.

\subsection{Animals and diets}

Seventeen lactating, primiparous $(n=8)$ and multiparous $(n=9)$, non-pregnant Holstein cows (initial mean \pm SE; body weight $[B W]=537 \pm 22 \mathrm{~kg}$, body condition score $[B C S]=$ $3.07 \pm 0.08$, milk yield $=26.0 \pm 1.2$, and days in milk $=76 \pm 2$ ) were assigned to the experiment ( $d-15$ to 210). On $d 0$, cows were ranked by parity, days in milk, milk yield, BW and BCS (Wildman et al., 1982), and assigned to one of three dietary treatments in a manner in which all treatment groups had equivalent parity distribution, and initial average days in milk, milk yield, BW and BCS: (1) concentrate intake to meet their requirements of net energy for lactation $\left(N E_{L}\right)$ without $\mathrm{Cr}$ supplementation $(M A N ; n=5),(2)$ concentrate intake to exceed their $\mathrm{NE}_{\mathrm{L}}$ requirements without $\mathrm{Cr}$ supplementation $(\mathrm{HIGH} ; n=6)$, and (3) HIGH with $2.5 \mathrm{~g}$ /daily of $\mathrm{Cr}$ propionate (HIGHCR; $n=6$, with $10 \mathrm{mg}$ of $\mathrm{Cr} /$ cow daily; KemTrace 0.4\% Cr; Kemin Agrifoods South America, Indaiatuba, São Paulo, Brazil). All dietary treatments were formulated to exceed $\mathrm{CP}$, mineral, and vitamin requirements (National Research Council (NRC) 2001), hence focusing treatment differences on $\mathrm{NE}_{\mathrm{L}}$ intake.

Cows were maintained, according to parity, in two drylot pens with ad libitum access to corn silage, water, and a commercial mineral mix without the inclusion of $\mathrm{Cr}(22 \% \mathrm{Ca}, 7.5 \% \mathrm{P}, 6.5 \% \mathrm{Na}$, $1.0 \% \mathrm{~K}, 3.6 \% \mathrm{Mg}, 2.0 \% \mathrm{~S}, 0.003 \% \mathrm{Co}, 0.115 \% \mathrm{Cu}, 0.004 \% \mathrm{I}, 0.220 \% \mathrm{Mn}$, $0.003 \% \mathrm{Se}, 0.400 \% \mathrm{Zn}, 400,000 \mathrm{IU} / \mathrm{kg}$ of vitamin A, $100,000 \mathrm{IU} / \mathrm{kg}$ of vitamin D3, and $0.150 \%$ of vitamin E) from d - 15 to 210 . Corn silage was provided in feed bunks that allowed $1.5 \mathrm{~m}$ of linear bunk space/cow and offered at daily rates to result in $\geq 15 \%$ (DM basis) of non-consumed silage, whereas the maximum daily provision of corn silage during the experiment was 13.9 and $11.6 \mathrm{~kg}$ of $\mathrm{DM} /$ cow for the multiparous and primiparous pens, respectively. Cows were milked twice daily in a side-by-side milking system $(0600$ and $1700 \mathrm{~h})$, and individually received a concentrate through self-locking head gates immediately after milking. Concentrate composition was (as-fed basis) $40.4 \%$ of soybean meal, $56.6 \%$ of ground corn, and $3.0 \%$ of the aforementioned commercial mineral mix. Twice monthly, 1 sample of the offered corn silage and 1 sample of the offered concentrate were collected. Samples of the same feedstuff were pooled into a single sample at the end of the experiment and analyzed for nutrient content via wet chemistry procedures by a bromatology laboratory (3rlab, Belo Horizonte, Brazil). Calculations of $\mathrm{NE}_{\mathrm{L}}$ and $\mathrm{NE}_{\mathrm{M}}$ used the equation proposed by the National Research Council (NRC) (2001). Concentration of DM was $40.5 \%$ in corn silage and $90.3 \%$ in the concentrate. Nutritive value (DM basis) was $5.81 \mathrm{MJ} / \mathrm{kg}$ of $\mathrm{NE}_{\mathrm{L}}$, $5.81 \mathrm{MJ} / \mathrm{kg}$ of $\mathrm{NE}_{\mathrm{M}}$, and $8.1 \%$ crude protein for corn silage, and $9.37 \mathrm{MJ} / \mathrm{kg}$ of $\mathrm{NE}_{\mathrm{L}}, 9.37 \mathrm{MJ} / \mathrm{kg}$ of $\mathrm{NE}_{\mathrm{M}}$, and $28.5 \%$ crude protein for concentrate.

From $d-15$ to 0 , all cows received the aforementioned concentrate without $\mathrm{Cr}$ supplementation as an adaptation period, whereas concentrate intake was formulated to each individual cow so the diet (concentrate + corn silage) provided $100 \%$ of their $\mathrm{NE}_{\mathrm{L}}$ requirements. From d 0 to 210, MAN cows continued to receive concentrate in amounts to allow their diets to provide $100 \%$ of their $\mathrm{NE}_{\mathrm{L}}$ requirements, whereas HIGH and HIGHCR cows received concentrate in amounts to allow their diets to provide $160 \%$ of their $\mathrm{NE}_{\mathrm{L}}$ requirements. Concentrate intake was adjusted weekly throughout the experimental period ( $d-15$ to 210) using the Spartan Dairy Ration Evaluator/Balancer (version 3.0; Michigan State University, East Lansing, MI, USA), according to treatment, parity, days in milk, milk yield, BW, and BCS, and corn silage intake estimated by the software. Chromium-propionate was offered in the amount recommended by the manufacturer $(2.5 \mathrm{~g} /$ cow daily of KemTrace; Kemin Agrifoods South America) and similar to previous research from our group (Leiva et al., 2014), mixed with $97.5 \mathrm{~g}$ of finely ground corn and top-dressed daily into the morning concentrate feeding of each HIGHCR cow. Finely ground corn ( $97.5 \mathrm{~g} / \mathrm{cow})$ was also top-dressed into the morning concentrate feeding of HIGH and MAN cows, but without the addition of the $\mathrm{Cr}$-propionate. Propionate intake was not adjusted among treatments because $2.5 \mathrm{~g}$ of additional propionate likely yields less variation on the variables assessed herein compared with the variation caused by sampling and measurement procedures. All cows completely consumed their concentrate allocation within 30 min after feeding.

\subsection{Sampling}

Cow BW, BCS, and milk production were recorded weekly during the experimental period ( $d-15$ to 210). These parameters were used to adjust concentrate intake of each cows on a weekly basis. Further, BCS was evaluated (Wildman et al., 1982) by the same two evaluators throughout the experiment, and evaluators were blinded to which treatment the assessed cow was assigned to.

Blood samples were collected weekly, prior to $(0 \mathrm{~h})$ and at 2 and $4 \mathrm{~h}$ after the morning concentrate feeding during the experiment for determination of serum glucose, insulin, and nonesterified fatty acids (NEFA; $0 \mathrm{~h}$ only) concentrations. Insulin to glucose ratio (I:G) was determined by dividing insulin and glucose concentrations within each sampling time (Bernhard et al., 2012). Concentrations of glucose, NEFA, and insulin obtained prior to feeding $(0 \mathrm{~h})$ were used to determine pre-prandial revised quantitative insulin sensitivity check index (RQUICKI). This methodology has been used to estimate insulin sensitivity in dairy cows (Grünberg et al., 2011), which is an approach to assess insulin resistance according to the equation proposed by Perseghin et al (2001): RQUICKI $=1 /[\log ($ glucose $)+\log ($ insulin $)+\log ($ NEFA $)]$.

Glucose tolerance tests (GTT) were performed on $\mathrm{d}-2,40,82$, 124,166 , and 208 of the experiment by intravenously infusing cows with $0.5 \mathrm{~g}$ of glucose $/ \mathrm{kg}$ of BW. More specifically, cows were weighed the day before each GTT, and had access to water but 
were not offered corn silage, mineral mix, Cr-propionate, or concentrate $12 \mathrm{~h}$ prior to and during the GTT. Cows were fitted with indwelling jugular catheters according to the procedures described by Curley et al. (2008) immediately prior to infusion, and received a $50 \%$ saline:dextrose solution via gravity intravenous infusion (Glicocalbos 50\%; Calbos Saúde Animal, Curitiba, Brazil) according to their BW (1 $\mathrm{g}$ of saline:dextrose solution $/ \mathrm{kg}$ of $\mathrm{BW}$ ). Across all GTT, total glucose infusion time was $10.1 \pm 0.7 \mathrm{~min}$. Catheters were removed after infusion was complete. Blood samples were collected at $-15,0,10,20,30,45,60,90$, and 120 min relative to infusion and analyzed for serum concentrations of glucose and insulin. During each GTT, area under the curve $(A U C)$ for glucose and insulin were calculated with the trapezoidal method (Shiang, 2004), whereas I:G was also determined within each sampling time (Bernhard et al., 2012). Glucose clearance rate and half-life were calculated with the equations described by Bernhard et al. (2012), using incremental serum glucose concentrations between 30 and 120 min post-infusion during the GTT.

During the weekly or GTT blood collections, samples were obtained from either the coccygeal vein or artery into commercial blood collection tubes (Vacutainer, $10 \mathrm{~mL}$; Becton Dickinson, Franklin Lakes, NJ, USA), placed immediately on ice, centrifuged at $3000 \times \mathrm{g}$ at $4{ }^{\circ} \mathrm{C}$ for $30 \mathrm{~min}$ for serum collection, and stored at $-20{ }^{\circ} \mathrm{C}$ on the same day of collection. Glucose was determined using a quantitative colorimetric kit (\#G7521; Pointe Scientific, Inc., Canton, MI, USA). Insulin was determined using a Coat-ACount kit (DPC Diagnostic Products Inc., Los Angeles, CA, USA) solid phase ${ }^{125}$ I radioimmunoassay. Concentrations of NEFA were determined using an enzymatic colorimetric kit (HR Series NEFA 2; Wako Pure Chemical Industries Ltd. USA, Richmond, VA, USA). The intra- and interassay CV were, respectively, 2.1 and $4.6 \%$ for glucose, 5.3 and $7.1 \%$ for insulin, and 1.9 and 3.8\% for NEFA. Assay sensitivity was $0.0005 \mathrm{mmol} / \mathrm{L}$ for glucose, $0.01 \mathrm{mmol} / \mathrm{L}$ for NEFA, and $0.02 \mu \mathrm{IU} / \mathrm{mL}$ for insulin.

\subsection{Reproductive management}

Follicle aspiration was performed on d $0,42,84,126,168$, and 210 of the experimental period to evaluate treatment effects on production of viable oocytes, as well as subsequent in vitro embryo production. Cows were at random stages of the estrous cycle when assigned to follicle aspiration, which was performed via transvaginal ovum pick-up (OPU) according to the procedures described by Bilby et al. (2006). Following OPU, the aspirate from each donor cow was filtered through a $75-\mu \mathrm{m}$ strainer (Watanabe Tecnologia Aplicada Ltda.; Cravinhos, Brazil) into a Petri dish, which was searched with a dissecting microscope for count and evaluation of oocytes recovered. More specifically, oocytes were classified according to morphologic characteristics into: (a) Grade I-homogenous cytoplasm, intact pellucid zone, in addition to 3 or more layers of cumulus ooforus cells, (b) Grade II-homogenous cytoplasm, intact pellucid zone, in addition to 2 layers of cumulus ooforus cells, (c) Grade III-homogenous cytoplasm, intact pellucid zone, in addition to 1 layer of cumulus ooforus cells, (d) denude oocytes-homogenous cytoplasm, intact pellucid zone, but no layers of cumulus ooforus cells, and (e) irregular oocytes-irregular cytoplasm and fragmented pellucid zone, independent of cumulus ooforus layers. Oocytes classified as Grade I, II, and III were considered viable and submitted to in vitro fertilization (IVF), whereas the remaining oocytes were considered non-viable for IVF and subsequently discarded. All oocytes were processed and maturated for IVF as described by Bilby et al. (2006), and fertilized with semen from the same sire according to the procedures described by Soto et al. (2003). Presumptive zygotes were incubated at $38.5{ }^{\circ} \mathrm{C}$ in $5 \% \mathrm{O}_{2}, 5 \% \mathrm{CO}_{2}$, in $100 \%$ humidified air for $7 \mathrm{~d}$ (Bilby et al., 2006). After incubation, number of cleaved and viable embryos was recorded with a dissecting microscope. Variables that were utilized for the present experiment were; number of oocytes collected that were viable to IVF (Grades I, II, and III), number of embryos produced, and ratio of embryos produced/viable oocytes collected within each sampling day.

\subsection{Statistical analysis}

All data were analyzed using cow as the experimental unit, cow (parity $\times$ treatment) as random variable, parity as independent variable, with the MIXED procedure of SAS (SAS Inst., Inc.; version 9.3) and Satterthwaite approximation to determine the denominator $\mathrm{df}$ for the tests of fixed effects. The model statement used for analysis of BW and BCS change, as well as initial and final BCS and BW during the experiment contained the effect of treatment. The model statement used for analysis of daily concentrate and estimated silage intake, as well as weekly BW, BCS, milk yield, serum NEFA, and RQUICKI contained the effects of treatment, time (day or week), and the resultant interaction. The model statement used for serum glucose, insulin, and I:G obtained during the weekly collections contained the effects of treatment, week, hour of sampling, and all resultant interactions. The model statement used for follicle aspiration and IVF outcomes contained the effects of treatment, day of follicle collection (d 42, 84, 126, 168, and 210), all resultant interactions, and values obtained from collection on $\mathrm{d}$ 0 as independent covariate. The model statement used for serum glucose, serum insulin, and I:G obtained during the GTT contained the effects of treatment, day of GTT (d 40,82, 124, 166, and 208), min of sampling, all resultant interactions, and mean values obtained from the GTT on d-2 as independent covariate. The model statement used for glucose and insulin AUC, glucose clearance rate, and glucose half-life contained the effects of treatment, day of GTT, all resultant interactions, and values obtained from the GTT on d-2 as independent covariate. The specified term for the repeated statement was week for the weekly collections, day for intake and reproductive variables, and hour for the GTT, with cow (parity $\times$ treatment) as subject. The covariance structure utilized for all repeated statements was compound symmetry, which provided the best fit for these analyses according to the Akaike information criterion. Results are reported as least square means, or covariately adjusted means for GTT and reproductive responses, and separated using PDIFF. Significance was set at $P \leq 0.05$, and tendencies were determined if $P \leq 0.05$ and $\leq 0.10$. Results are reported according to treatment effects if no interactions were significant, or according to the highest-order interaction detected.

\section{Results and discussion}

According to the experimental design, daily concentrate intake (DM basis) was less $(P \leq 0.02)$ in MAN vs. HIGH and HIGHCR cows (7.1, 11.1, and $10.4 \mathrm{~kg} / \mathrm{cow}$ daily; $\mathrm{SEM}=0.88)$, and similar $(P=0.53)$ between HIGH and HIGHCR cows. Estimated corn silage intake (DM basis) was similar among all treatments (11.5, 11.1, and $11.1 \mathrm{~kg} / \mathrm{d} ; \mathrm{SEM}=0.16$ ), although cows were group-fed corn silage within parities and individual corn silage intake was not evaluated. No treatment effects were detected for final BW $(P=0.18)$ and BW change $(P=0.86)$, despite the designed differences in concentrate and total $\mathrm{NE}_{\mathrm{L}}$ intake between HIGHCR and HIGH compared with MAN cows (Table 1). However, changes in BW include synthesis of body tissues as well as fluctuations in feed and water consumption, whereas BCS reflects the body tissue status without being influenced by the content of the gastrointestinal tract. Hence, BCS better indicates nutritional status than BW changes in dairy cattle (West et al., 1990). Accordingly, BCS change during the experiment was greater $(P \leq 0.04)$ in HIGH and HIGHCR compared with MAN 
Table 1

Body weight $(B W)$, body condition score $(B C S)$, and milk yield of lactating dairy cows assigned to: (1) concentrate intake to provide $100 \%$ of their $\mathrm{NE}_{\mathrm{L}}$ requirements without $\mathrm{Cr}$ supplementation (MAN; $n=5)$, (2) concentrate intake to provide $160 \%$ of their $\mathrm{NE}_{\mathrm{L}}$ requirements without $\mathrm{Cr}$ supplementation $(\mathrm{HIGH} ; n=6)$, and (3) HIGH with $2.5 \mathrm{~g} / \mathrm{d}$ of $\mathrm{Cr}$-propionate (HIGHCR; $\mathrm{n}=6$, with $10 \mathrm{mg}$ of $\mathrm{Cr} / \mathrm{cow}$ daily).,

\begin{tabular}{llllll}
\hline Item & HIGH & HIGHCR & MAN & SEM & $P$-value \\
\hline Body weight, kg & & & & & \\
$\quad$ Initial BW (d 0), kg & 566 & 527 & 502 & 29 & 0.32 \\
$\quad$ Final BW (d 88), kg & 611 & 571 & 537 & 26 & 0.18 \\
BW change, kg & 45.1 & 44.1 & 34.6 & 14.6 & 0.86 \\
& & & & & \\
BCS ${ }^{c}$ & & & & & \\
$\quad$ Initial BCS (d 0) & 3.00 & 3.04 & 3.22 & 0.16 & 0.65 \\
$\quad$ Final BCS (d 88) & 3.58 & 3.87 & 3.44 & 0.23 & 0.42 \\
$\quad$ BCS change & $0.58^{\text {a }}$ & $0.83^{\text {a }}$ & $0.23^{\text {b }}$ & 0.12 & 0.01 \\
& & & & & \\
Milk production, kg/d & 20.8 & 19.7 & 19.7 & 2.4 & 0.92 \\
\hline
\end{tabular}

a During the experimental period (d 0 to 210), all cows received corn silage for ad libitum consumption and were offered a concentrate based on corn, soybean meal, and commercial mineral mix (56.6:40.4:3.0 ratio; as-fed basis). Chromiumpropionate ( $2.5 \mathrm{~g}$ of KemTrace $0.4 \% \mathrm{Cr}$; Kemin Agrifoods South America) was mixed with $97.5 \mathrm{~g}$ of finely ground corn, and top-dressed daily into the morning concentrate feeding of each HIGHCR cow.

${ }^{\mathrm{b}}$ Means with different superscripts $(\mathrm{a}, \mathrm{b})$ differ $(P<0.05)$.

c According to Wildman et al. (1982).

cows (Table 1), although no treatment effects were detected $(P \geq 0.42)$ for final BCS (Table 1$)$. Given that corn silage intake was not evaluated herein, one can speculate that the greater concentrate feeding to HIGH and HIGHCR cows depressed their corn silage intake (Conrad et al., 1964) beyond the predicted by the model (Spartan Dairy Ration Evaluator/Balancer, version 3.0) and resulted in comparable $\mathrm{NE}_{\mathrm{L}}$ intake among all treatments, which could explain the lack of major treatment effects on final BW and BCS (Table 1). Nevertheless, Leiva et al. (2014) also reported that BW parameters were similar, whereas BCS change was greater in non-lactating dairy cows consuming excessive energy compared to cohorts with adequate energy intake. Therefore, HIGH and HIGHCR cows deposited more body tissues during the experimental period compared with MAN cows, corroborating with the designed differences in concentrate and total $\mathrm{NE}_{\mathrm{L}}$ intake among treatments.

Within samples collected weekly, no treatment effects were detected $(P=0.79)$ for serum glucose concentrations (Table 2). Circulating glucose concentrations are influenced positively by energy intake (Butler, 2003). Therefore, it would be expected that serum glucose would be reduced in MAN compared with HIGH and HIGHCR cows, particularly because Leiva et al. (2014) reported that non-lactating cows consuming excessive energy had greater serum glucose concentrations compared with cohorts consuming adequate energy. The lack of treatment effects on serum glucose concentrations may also be associated, as previously discussed, with depressed their corn silage intake in HIGH and HIGHCR cows and comparable $\mathrm{NE}_{\mathrm{L}}$ intake among all treatments. Nevertheless, serum glucose concentrations are fairly stable in ruminants due to its homeostatic regulation (Bauman and Currie, 1980), particularly in lactating cattle due to glucose uptake by the mammary gland (Bickerstaffe et al., 1974), which may have hindered the expected treatments effects on this variable.

Within samples collected weekly, a treatment $\times$ day interaction was detected $(P<0.01)$ for serum insulin concentrations (Fig. 1). Serum insulin concentrations were often greater $(P \leq 0.05)$ for HIGH cows, intermediate for HIGHCR cows, and the lowest for MAN cows beginning on d 14 of the experiment period (Fig. 1). Circulating insulin concentrations are also associated positively by

\section{Table 2}

Serum parameters and revised quantitative insulin sensitivity check index (RQUICKI) of lactating dairy cows assigned to: (1) concentrate intake to provide $100 \%$ of their $\mathrm{NE}_{\mathrm{L}}$ requirements without $\mathrm{Cr}$ supplementation (MAN; $n=5$ ) (2) concentrate intake to provide $160 \%$ of their $\mathrm{NE}_{\mathrm{L}}$ requirements without $\mathrm{Cr}$ supplementation (HIGH; $n=6$ ), and (3) HIGH with $2.5 \mathrm{~g} / \mathrm{d}$ of $\mathrm{Cr}$-propionate (HIGHCR $n=6$, with $10 \mathrm{mg}$ of $\mathrm{Cr} / \mathrm{cow}$ daily)., ${ }^{\mathrm{a}}$

\begin{tabular}{|c|c|c|c|c|c|}
\hline Item & HIGH & HIGHCR & MAN & SEM & $P$-value \\
\hline \multicolumn{6}{|l|}{ Weekly collections ${ }^{\mathrm{c}}$} \\
\hline Serum glucose, $\mathrm{mmol} / \mathrm{L}$ & 3.42 & 3.42 & 3.51 & 0.11 & 0.79 \\
\hline Serum NEFA, mmol/L & $0.143^{\mathrm{a}}$ & $0.154^{\mathrm{a}}$ & $0.176^{\mathrm{b}}$ & 0.007 & 0.02 \\
\hline RQUICKI & 0.628 & 0.706 & 0.675 & 0.060 & 0.65 \\
\hline \multicolumn{6}{|l|}{ Glucose tolerance test ${ }^{\mathrm{d}}$} \\
\hline Serum glucose, $\mathrm{mmol} / \mathrm{L}$ & 8.16 & 8.84 & 8.71 & 0.55 & 0.46 \\
\hline $\begin{array}{l}\text { Glucose-area under the curve, } \\
\mathrm{mmol} / \mathrm{L} \cdot \mathrm{min}\end{array}$ & 963 & 1.079 & 1,051 & 75 & 0.41 \\
\hline $\begin{array}{l}\text { Insulin-area under the curve, } \\
\mu \mathrm{IU} / \mathrm{mL} \cdot \min \end{array}$ & $6.426^{\mathrm{a}}$ & $5.391^{\mathrm{a}, \mathrm{b}}$ & $4.272^{\mathrm{b}}$ & 496 & 0.04 \\
\hline Glucose clearance rate, $\% / \mathrm{min}$ & 1.205 & 1.007 & 1.107 & 0.086 & 0.28 \\
\hline Glucose half-life, min & 60.9 & 75.0 & 70.5 & 6.9 & 0.34 \\
\hline
\end{tabular}

auring the experimental period (d 0 to 210 ), all cows received corn silage for ad libitum consumption and were offered a concentrate based on corn, soybean meal, and commercial mineral mix (56.6:40.4:3.0 ratio; as-fed basis). Chromiumpropionate ( $2.5 \mathrm{~g}$ of KemTrace $0.4 \% \mathrm{Cr}$; Kemin Agrifoods South America) was mixed with $97.5 \mathrm{~g}$ of finely ground corn, and top-dressed daily into the morning concentrate feeding of each HIGHCR cow.

${ }^{\mathrm{b}}$ Means with different superscripts $(\mathrm{a}, \mathrm{b})$ differ $(P<0.05)$.

c Blood samples were collected weekly, prior to $(0 \mathrm{~h})$ and at 2 and $4 \mathrm{~h}$ after the morning concentrate feeding.

d Glucose tolerance tests (GTT) were performed on d - 2, 40,82,124, 166, and 208 by intravenously infusing cows with $0.5 \mathrm{~g}$ of glucose $/ \mathrm{kg}$ of BW. Blood samples were collected at 15, 0, 10, 20, 30, 45, 60, 90, and 120 min relative to infusion. Area under the curve for glucose and insulin were calculated with the trapezoidal method (Shiang, 2004). Glucose clearance rate and half-life were calculated with the equations described by Bernhard et al. (2012).

energy intake (Butler, 2003). Therefore, the greater serum insulin concentrations often detected in HIGH and HIGHCR compared with MAN cows could be attributed to their greater energy intake during the experimental period, supporting the designed differences in concentrate intake and treatment effects detected on BCS change. However, serum insulin concentrations were also often greater in HIGH compared with HIGHCR cows despite their similar designed concentrate intake and glucose concentrations. Hence, treatment differences on serum insulin cannot be exclusively attributed to rate of energy intake; perhaps should be associated with increased insulin resistance and subsequent hyperinsulinemia in HIGH cows as suggested by Leiva et al. (2014). Accordingly, a treatment $\times$ day interaction was also detected $(P<0.01)$ for I:G in samples collected weekly, which is positively associated with insulin resistance in cattle (Subiyatno et al., 1996; Hayirli et al., 2001). The I:G values were often greater $(P \leq 0.05)$ for HIGH cows, intermediate for HIGHCR cows, and the lowest for MAN cows beginning on d 14 of the experiment period (Fig. 2). Collectively, treatment differences detected for serum insulin and I:G indicate that excessive energy intake increased insulin resistance in HIGH cows compared with MAN cohorts, whereas $\mathrm{Cr}$ propionate supplementation alleviated this outcome. Similarly, Leiva et al. (2014) reported that Cr-propionate supplementation prevented the increase in insulin resistance caused by excessive energy intake in non-lactating dairy cows. The lack of treatment $\times$ hour of sampling $(P=0.73)$ indicate that $\mathrm{I}: G$ can be used to evaluate insulin sensitivity of dairy cows in blood samples collected prior to or after feeding.

Within samples collected twice weekly but before the morning feeding $(0 \mathrm{~h})$, serum NEFA concentration was greater $(P \leq 0.05)$ in MAN compared with HIGH and HIGHCR cows, and did not differ $(P=0.30)$ between HIGHCR and HIGH cows (Table 2). Circulating 


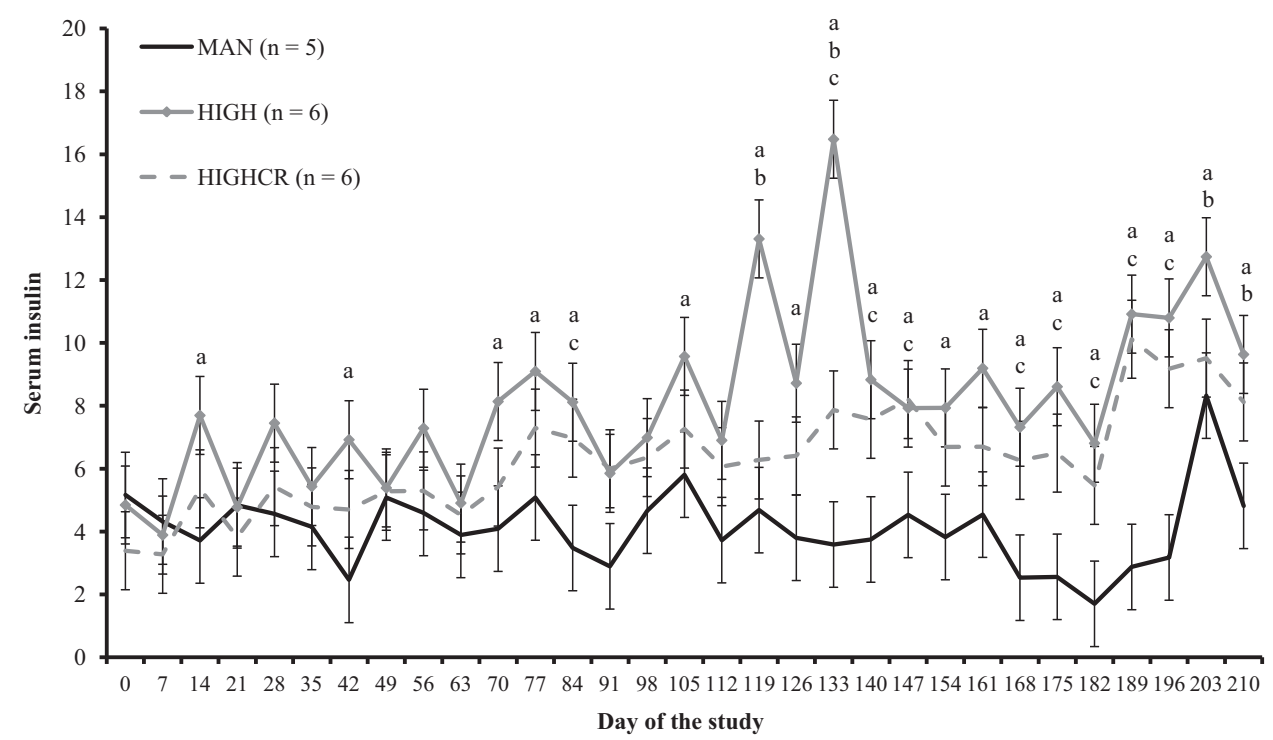

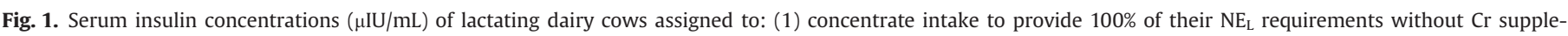

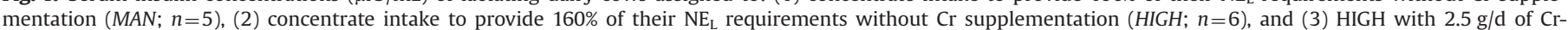

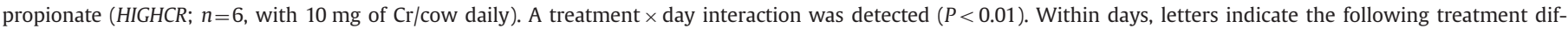
ferences $(P \leq 0.05) ; \mathrm{a}=$ HIGH vs. MAN, $\mathrm{b}=\mathrm{HIGH}$ vs. HIGHCR, and $\mathrm{c}=$ HIGHCR vs. MAN

NEFA concentrations are negatively associated with energy intake in lactating dairy cattle (Grummer, 1995), which further supports that HIGHCR and HIGH cows consumed more $\mathrm{NE}_{\mathrm{L}}$ than MAN cows. Based on serum glucose, insulin, and NEFA concentrations obtained prior to the morning feeding, no treatment effects were detected for RQUICKI ( $P=0.65$; Table 2). Leiva et al. (2014) reported that non-lactating dairy cows consuming excessive energy intake reduced RQUICKI compared with cohorts consuming adequate energy, whereas $\mathrm{Cr}$-propionate supplementation prevented this outcome. The reason for the discrepancy between RQUICKI results from this experiment compared with Leiva et al. (2014) may be associated with serum NEFA, which is a component of the RQUICKI equation (Perseghin et al., 2001). More specifically, Leiva et al. (2014) reported that excessive energy intake increased serum NEFA concentrations in non-lactating cows, and attributed this outcome to increased insulin resistance and consequent mobilization of body fat reserves to compensate for the reduced uptake of glucose by body tissues. Others have also associated RQUICKI with insulin resistance in early-lactation dairy cows, which experience elevated circulating NEFA to account for energy deficit (Stengärde et al., 2010; Grünberg et al., 2011). In the present study, the cows utilized differed from Leiva et al. (2014) by being lactating, and differed from research with early lactating cows (Stengärde et al., 2010; Grünberg et al., 2011) by being in positive nutritional balance based on BW and BCS change (Table 1); hence experienced different NEFA metabolism. Consequently, RQUICKI may not be a viable indicator of insulin resistance in lactating dairy cows in positive energy balance due to different NEFA metabolism compared with that of non-lactating cows or lactating cows in negative energy balance. Supporting this rationale, Schoenberg

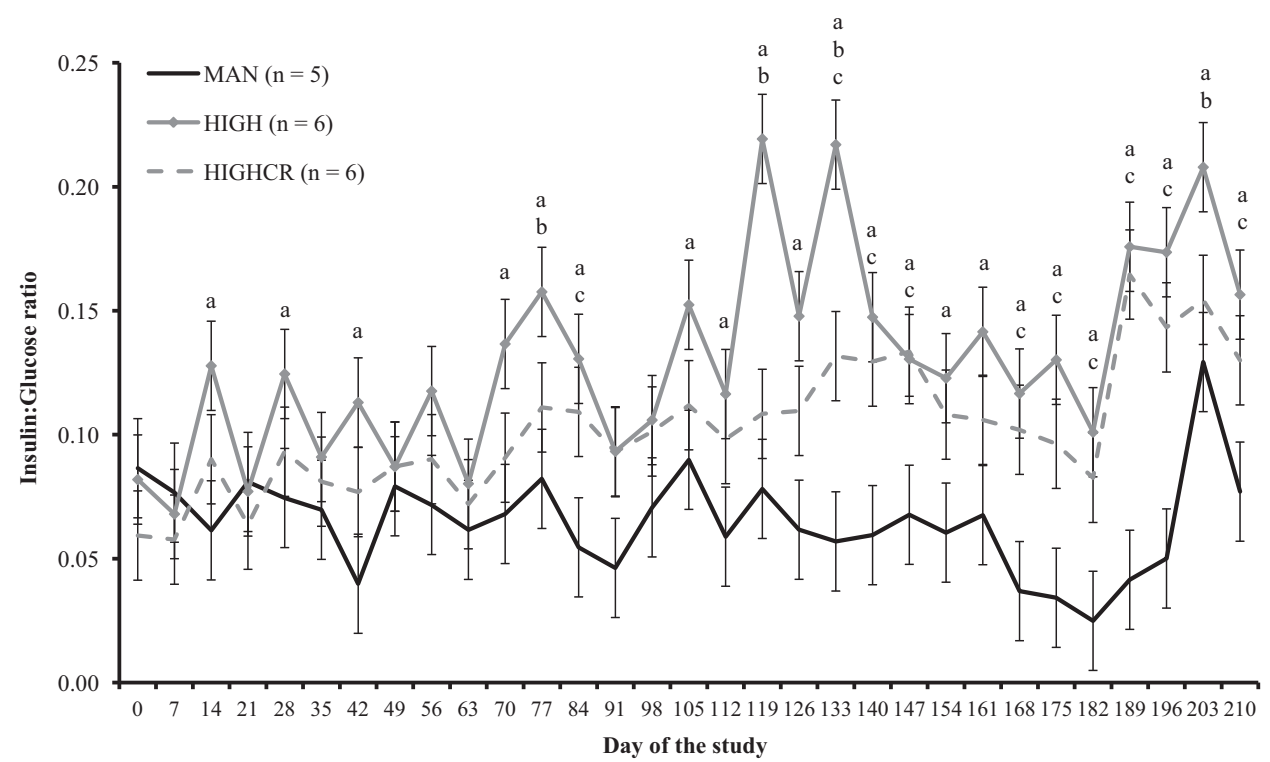

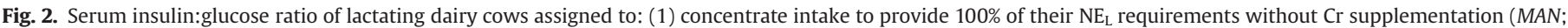

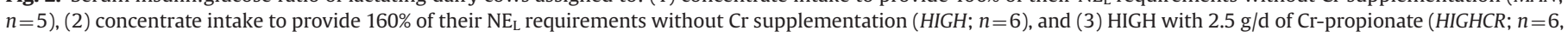

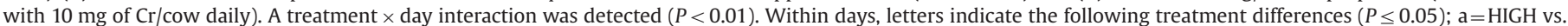
MAN, $b=$ HIGH vs. HIGHCR, and $c=$ HIGHCR vs. MAN 


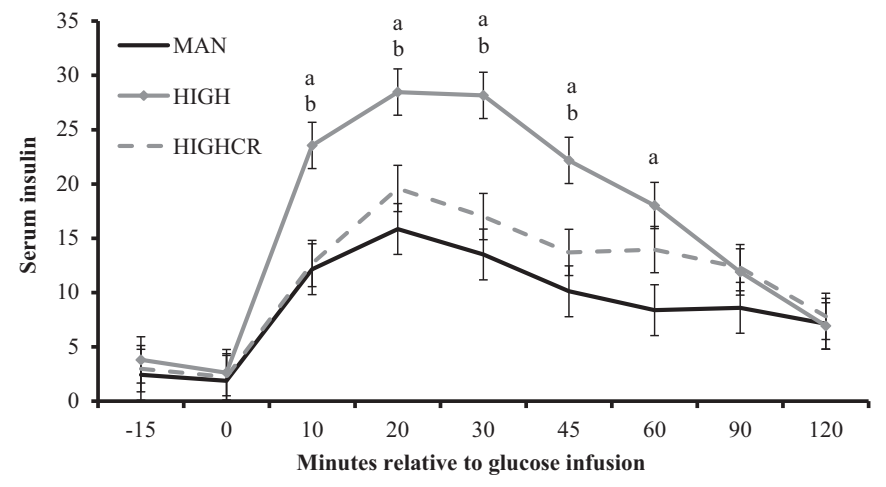

Fig. 3. Serum insulin concentrations $(\mu \mathrm{IU} / \mathrm{mL}$ ) following a glucose tolerance test (intravenous infusion of $0.5 \mathrm{~g}$ of glucose $/ \mathrm{kg}$ of body weight at $0 \mathrm{~min}$ ) of lactating dairy cows assigned to: (1) concentrate intake to provide $100 \%$ of their $\mathrm{NE}_{\mathrm{L}}$ requirements without $\mathrm{Cr}$ supplementation (MAN; $n=5)$, (2) concentrate intake to provide $160 \%$ of their $\mathrm{NE}_{\mathrm{L}}$ requirements without $\mathrm{Cr}$ supplementation $(\mathrm{HIGH} ; n=6)$, and (3) HIGH with $2.5 \mathrm{~g} / \mathrm{d}$ of Cr-propionate (HIGHCR; $n=6$, with $10 \mathrm{mg}$ of $\mathrm{Cr} / \mathrm{cow}$ daily). A treatment $\times$ min interaction was detected $(P<0.01)$. Within min, letters indicate the following treatment differences $(P \leq 0.05)$; $a=H I G H$ vs. MAN, $b=H I G H$ vs. HIGHCR

and Overton (2011) suggested that using RQUICKI to assess insulin resistance in cows of different energy and lactation status should be done with caution and results should be interpreted within cows of similar metabolic state, given that RQUICKI may be an appropriate measure in some metabolic circumstances but may lack the ability to detect differences in others.

During the GGTs, no treatment effects were detected $(P \geq 0.28)$ for serum glucose, glucose AUC, glucose clearance rate, and glucose half-life (Table 2), which corroborates the results from weekly samples. However, a treatment $\times$ min interactions were detected $(P<0.01)$ for serum insulin (Fig. 3) and I:G (Fig. 4), given that these parameters were greater $(P \leq 0.05)$ for HIGH compared with HIGHCR and MAN from 10 to 60 min relative to glucose infusion, but always similar between HIGHCR and MAN $(P \geq 0.21)$. Insulin AUC was also greater $(P=0.02)$ for HIGH compared with MAN, and similar $(P \geq 0.17)$ between HIGHCR and MAN as well as HIGHCR and HIGH cows (Table 2). Collectively, treatment effects detected during the GTT for serum insulin and I:G further support the outcomes detected during the weekly collections. Serum insulin and I:G differences between MAN and HIGH cows indicate that excessive energy intake increased insulin resistance in lactating dairy cows following a GTT. Differences in the same parameters

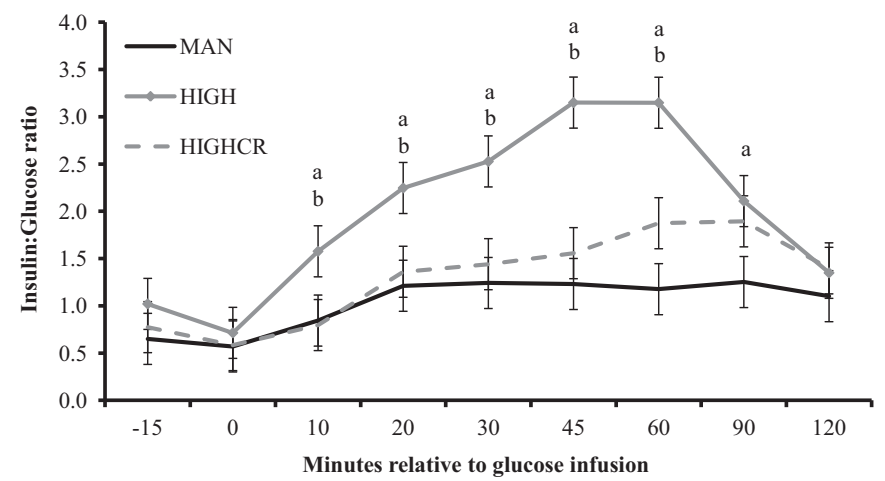

Fig. 4. Insulin:glucose ratio following a glucose tolerance test (intravenous infusion of $0.5 \mathrm{~g}$ of glucose $/ \mathrm{kg}$ of body weight at $0 \mathrm{~min}$ ) of lactating dairy cows assigned to: (1) concentrate intake to provide $100 \%$ of their $\mathrm{NE}_{\mathrm{L}}$ requirements without $\mathrm{Cr}$ supplementation (MAN;n=5), (2) concentrate intake to provide $160 \%$ of their $\mathrm{NE}_{\mathrm{L}}$ requirements without $\mathrm{Cr}$ supplementation $(\mathrm{HIGH} ; n=6)$, and (3) HIGH with $2.5 \mathrm{~g} / \mathrm{d}$ of $\mathrm{Cr}$-propionate (HIGHCR; $n=6$, with $10 \mathrm{mg}$ of $\mathrm{Cr} /$ cow daily). A treatment $\times$ min interaction was detected $(P<0.01)$. Within $\mathrm{min}$, letters indicate the following treatment differences $(P \leq 0.05) ; \mathrm{a}=\mathrm{HIGH}$ vs. MAN, $\mathrm{b}=$ HIGH vs. HIGHCR. between HIGHCR and HIGH cows, in addition to the similar responses between HIGHCR and MAN cows also indicate that $\mathrm{Cr}$ propionate supplementation prevented the increase in insulin resistance caused by excessive energy intake in lactating dairy cows following a GTT.

Supporting our hypothesis and our previous research with nonlactating cattle (Leiva et al., 2014), this experiment demonstrated that lactating dairy cows consuming excessive energy experience increased insulin resistance during routine management and following a GTT. The physiological reason to why excessive energy intake causes insulin resistance in cattle is still not fully comprehended, but may be attributed to the increased lipogenesis, given that lipids interfere with the binding of insulin to its cellular receptors (Lewis et al., 2002; Ferezou and Bach, 1999). Leiva et al. (2014) also associated excessive energy intake and insulin resistance with elevated serum NEFA, given that cellular NEFA metabolism interferes with the intracellular insulin receptor signaling cascade (Lewis et al., 2002). However, in the present experiment, serum NEFA concentrations were not increased by excessive energy intake as previously discussed, likely due to the lactation and nutritional status of the animals. Hence, increased insulin resistance in the HIGH cows utilized herein should be associated, at least partially, with greater lipogenesis caused by excessive energy intake, as suggested by treatment effects detected for BCS change (Table 1).

Supporting our results regarding $\mathrm{Cr}$-propionate supplementation, research with cattle receiving growing diets reported that supplemental $\mathrm{Cr}$ enhances glucose metabolism parameters (Chang and Mowat, 1992; Mowat et al., 1993). Others also reported that supplemental $\mathrm{Cr}$ enhanced insulin sensitivity and glucose metabolism following GTT in periparturient dairy cows (Subiyatno et al., 1996; Hayirli et al., 2001). Leiva et al. (2014) reported that $\mathrm{Cr}$ propionate supplementation reduced insulin resistance, in samples collected or not during a GTT, in non-lactating cows consuming excessive energy. Hence, $\mathrm{Cr}$-propionate supplementation appears to mitigate the decrease in insulin sensitivity caused by excessive energy intake in cattle with different lactation and nutritional status. Chromium is a critical component of the glucose tolerance factor that facilitates the action of insulin on body cells (Mertz, 1992), and Cr supplementation has been shown to enhance glucose metabolism in ruminants (McNamara and Valdez, 2005; Sumner et al., 2007). More specifically, Cr modifies glucose metabolism through chromodulin, an oligopeptide that binds with high affinity to four chromic ions and enables $\mathrm{Cr}$ to be involved in the autoamplification of insulin signaling, maintaining the active conformation of insulin receptors and promoting greater glucose uptake (Vincent, 2001). To our knowledge, this is the first research indicating that excessive energy intake also results in increased insulin resistance in lactating dairy cattle, and $\mathrm{Cr}$-propionate supplementation alleviates this outcome. As suggested by Leiva et al. (2014), Cr-propionate supplementation appears to mitigate the negative interference of excessive energy intake and subsequent increased lipogenesis on mechanisms that modulate insulin sensitivity, such as activity of insulin on target receptors and cells (Lewis et al., 2002; Ferezou and Bach, 1999). Nevertheless, excessive energy intake and $\mathrm{Cr}$-propionate supplementation may also impact insulin resistance parameters in adipose and other body tissues through immunological signals such as proinflammatory cytokine response (Wellen and Hotamisligil, 2005). However, this experiment was not designed to investigate the specific cellular mechanisms associating excessive energy intake, Cr-propionate supplementation, and insulin sensitivity in lactating dairy cows. Therefore, additional research is still warranted to further comprehend the physiological mechanisms responsible for the outcomes observed herein.

No treatment effect was detected for milk production $(P=0.92$; 
Table 3

Oocyte collection and in vitro embryo production from lactating dairy cows assigned to: (1) concentrate intake to provide $100 \%$ of their $\mathrm{NE}_{\mathrm{L}}$ requirements without $\mathrm{Cr}$ supplementation (MAN; $n=5$ ), (2) concentrate intake to provide $160 \%$ of their $\mathrm{NE}_{\mathrm{L}}$ requirements without $\mathrm{Cr}$ supplementation $(\mathrm{HIGH} ; n=6)$, and (3) HIGH with $2.5 \mathrm{~g} / \mathrm{d}$ of Cr-propionate (HIGHCR; $n=6$, with $10 \mathrm{mg}$ of $\mathrm{Cr} / \mathrm{cow}$ daily). a,b,c

\begin{tabular}{llllll}
\hline Item & HIGH & HIGHCR & MAN & SEM & $P$-value \\
\hline Oocytes per collection, $n$ & 6.9 & 12.6 & 7.2 & 3.3 & 0.39 \\
Embryos produced per collections, $n$ & 1.8 & 5.0 & 4.1 & 1.7 & 0.34 \\
Embryo produced/oocyte collected & $0.22^{\mathrm{a}}$ & $0.29^{\mathrm{a}}$ & $0.66^{\mathrm{b}}$ & 0.09 & 0.02 \\
\hline
\end{tabular}

a During the experimental period ( $\mathrm{d} 0$ to 210 ), all cows received corn silage for ad libitum consumption and were offered a concentrate based on corn, soybean meal, and commercial mineral mix (56.6:40.4:3.0 ratio; as-fed basis). Chromiumpropionate ( $2.5 \mathrm{~g}$ of KemTrace $0.4 \% \mathrm{Cr}$; Kemin Agrifoods South America) was mixed with $97.5 \mathrm{~g}$ of finely ground corn, and top-dressed daily into the morning concentrate feeding of each HIGHCR cow.

${ }^{\mathrm{b}}$ Means with different superscripts $(\mathrm{a}, \mathrm{b}) \operatorname{differ}(P<0.05)$

${ }^{c}$ Follicle aspiration was performed on d 0, 42, 84, 126, 168, and 210 via transvaginal ovum pick-up (OPU), processed and maturated for in vitro fertilization (Bilby et al., 2006), and fertilized with semen from the same sire (Soto et al., 2003). Presumptive zygotes were incubated for $7 \mathrm{~d}$ (Bilby et al., 2006). After incubation, number of cleaved and viable embryos was recorded. Values obtained on d 0 served as covariate; therefore, values reported are covariately-adjusted means.

Table 1), despite treatment differences detected for insulin resistance parameters, and the negative impacts attributed to this syndrome on milk yield of lactating dairy cattle (LeBlanc, 2010). Nevertheless, all treatments provided $\geq 100 \%$ of $\mathrm{NE}_{\mathrm{L}}$, which allowed all cows to produce their maximum milk yield while the additional energy supplied by HIGH and HIGHCR was likely converted into BCS (Table 1). In addition, milk components and subsequent FCM, SCM, and protein-corrected milk were not evaluated, whereas insulin is known to impact mammary synthesis of milk constituents, particularly protein (McGuire et al., 1995). Potential treatment differences in milk components could also support the lack of treatment effects on serum glucose concentrations, given that the mammary gland utilizes circulating glucose for lactose synthesis (Rigout et al., 2002). On the other hand, one can speculate that the degree of insulin resistance elicited by the treatments evaluated herein were not sufficient to impact milk yield. Moreover, the milk yield capacity of cows utilized in the present experiment were not as elevated compared with the high-producing Holstein cows denoted by LeBlanc (2010). Therefore, additional research is still required to assess the impacts of insulin resistance caused by excessive energy intake, as well as the impacts of $\mathrm{Cr}$-propionate supplementation, on milk synthesis parameters in high-producing lactating dairy cattle.

No treatment effects were detected $(P \geq 0.32)$ for number of viable oocytes collected or embryos produced (Table 3$)$. However, a treatment effect was detected $(P=0.02)$ for proportion of embryo produced per oocyte collected, which was greater $(P \leq 0.02)$ for MAN cows compared with HIGH and HIGHCR, but similar $(P=0.59)$ between HIGH and HIGHCR cows (Table 3$)$. These results suggest that excessive energy intake and the subsequent increase in insulin resistance impacted oocyte fertility. Accordingly, Adamiak et al. (2005) reported that non-lactating heifers that were hyperinsulinemic, and hence experienced increased insulin resistance, had lower blastocyst yields compared with control cohorts with adequate plasma insulin concentrations. More specifically, hyperinsulinemia is believed to impair oocyte fertility by reducing mRNA concentrations of IGF-I binding proteins as well as insulin receptors within small follicles (Armstrong et al., 2001), although the precise mechanisms associated with this outcome are yet to be understood (Adamiak et al., 2005). The lack of differences for reproductive variables between HIGH and HIGHCR cows indicate that $\mathrm{Cr}$-propionate supplementation failed to alleviate the detrimental effects of excessive energy intake on oocyte production and fertility, although others have reported reproductive benefits of organic $\mathrm{Cr}$ supplementation to dairy cows (Bryan et al., 2004; Soltan et al., 2010). Therefore, research is still warranted to develop strategies that mitigate potential reproductive losses caused by excessive energy intake and subsequent increase in insulin resistance in lactating dairy cattle.

\section{Conclusion}

Results from this experiment indicate that lactating dairy cows consuming excessive concentrate and $\mathrm{NE}_{\mathrm{L}}$ experienced increased insulin resistance and reduced proportion of embryo produced per oocyte collected compared with cows consuming adequate amounts of energy, whereas Cr-propionate supplementation was effective in reducing insulin resistance parameters but not reproductive losses. However, no substantial treatment effects were detected on milk yield, although insulin resistance has been negatively associated with performance responses in dairy cattle (LeBlanc, 2010). Nevertheless, research is still warranted to further evaluate the impacts of excessive energy intake and $\mathrm{Cr}$-propionate supplementation on productive and reproductive parameters of lactating dairy cattle, including evaluation of milk constituents and pregnancy outcomes in high-producing dairy cows.

\section{Conflicts of interest}

No conflicts of interest to report.

\section{Acknowledgments}

The Fundação de Amparo à Pesquisa do Estado de São Paulo (São Paulo, Brazil) provided financial support for this research (grant \# 2012/24816-7), as well as scholarship for T. Leiva (grant \# 2012/25390-3).

\section{References}

Adamiak, S.J., Mackie, K., Watt, R.G., Webb, R., Sinclair, K.D., 2005. Impact of nutrition on oocyte quality: cumulative effects of body composition and diet leading to hyperinsulinemia in cattle. Biol. Reprod. 73, 918-926.

Armstrong, D.G., McEvoy, T.G., Baxter, G., Robinson, J.J., Hogg, C.O., Woad, K.J., Webb, R., Sinclair, K.D., 2001. Effect of dietary energy and protein on bovine follicular dynamics and embryo production in vitro: associations with the ovarian insulin-like growth factor system. Biol. Reprod. 64, 1624-1632.

Bauman, D.E., Currie, W.B., 1980. Partitioning of nutrients during pregnancy and lactation: a review of mechanisms involving homeostasis and homeorhesis. J. Dairy Sci. 63, 1514-1529.

Bernhard, B.C., Burdick, N.C., Rathmann, R.J., Carroll, J.A., Finck, D.N., Jennings, M.A., Young, T.R., Johnson, B.J., 2012. Chromium supplementation alters both glucose and lipid metabolism in feedlot cattle during the receiving period. J. Anim. Sci. 90, 4857-4865.

Bickerstaffe, R., Annison, E.F., Linzell, J.L., 1974. The metabolism of glucose, acetate, lipids and amino acids in lactating dairy cows. J. Agric. Sci. 82, 71-85.

Bilby, T.R., Block, J., do Amaral, B.C., Sa Filho, O., Silvestre, F.T., Hansen, P.J., Staples, C. R., Thatcher, W.W., 2006. Effects of dietary unsaturated fatty acids on oocyte quality and follicular development in lactating dairy cows in summer. J. Dairy Sci. 89, 3891-3903.

Bryan, M.A., Socha, M.T., Tomlinson, D.J., 2004. Supplementing intensively grazed late-gestation and early-lactation dairy cattle with chromium. J. Dairy Sci. 87, 4269-4277.

Butler, W.R., 2003. Energy balance relationships with follicular development, ovulation and fertility in postpartum dairy cows. Livest. Prod. Sci. 83, 211-218.

Chang, X., Mowat, D.N., 1992. Supplemental chromium for stressed and growing feeder calves. J. Anim. Sci. 70, 559-565.

Conrad, H.R., Pratt, A.D., Hibbs, J.W., 1964. Regulation of feed intake in dairy cows. I. Change in importance of physical and physiological factors with increasing digestibility. J. Dairy Sci. 47, 54-62.

Curley, K.O., Neuendorff, D.A., Lewis, A.W., Cleere, J.J., Welsh Jr., T.H., Randel, R.D. 2008. Functional characteristics of the bovine hypothalamic-pituitary-adrenal 
axis vary with temperament. Horm. Behav. 53, 20-27.

Ferezou, J., Bach, A.C. 1999. Structure and metabolic fate of triacylglycerol- and phospholipid-rich particles of commercial parenteral fat emulsions. Nutrition $15,44-50$.

Grummer, R.R., 1995. Impact of changes in organic nutrient metabolism on feeding the transition dairy cow. J. Anim. Sci. 73, 2820-2833.

Grünberg, W., Donkin, S.S., Constable, P.D., 2011. Periparturient effects of feeding a low dietary cation-anion difference diet on acid-base, calcium, and phosphorus homeostasis and on intravenous glucose tolerance test in high-producing dairy cows. J. Dairy Sci. 94, 727-745.

Hayirli, A., Bremmer, D.R., Bertics, S.J., Socha, M.T., Grummer, R.R., 2001. Effect of chromium supplementation on production and metabolic parameters in periparturient dairy cows. J. Dairy Sci. 84, 1218-1230.

LeBlanc, S., 2010. Monitoring metabolic health of dairy cattle in the transition period. J. Reprod. Dev. 56, S29-S35.

Leiva, T., Cooke, R.F., Aboin, A.C., Drago, F.L., Gennari, R., Vasconcelos, J.L.M., 2014 Effects of excessive energy intake and supplementation with chromium propionate on insulin resistance parameters in non-lactating dairy cows. J. Anim. Sci. 92, 775-782.

Lewis, G.F., Carpentier, A., Adehi, K., Giaccca, A., 2002. Disordered fat storage and mobilization in the pathogenesis of insulin resistance and type 2 diabetes. Endocr. Rev. 23, 201-229.

McGuire, M.A., Griinari, J.M., Dwyer, D.A., Bauman, D.E., 1995. Role of insulin in the regulation of mammary synthesis of fat and protein. J. Dairy Sci. 78, 816-824.

McNamara, J.P., Valdez, F., 2005. Adipose tissue metabolism and production responses to calcium propionate and chromium propionate. J. Dairy Sci. 88, 2498-2507.

Mertz, W., 1992. Chromium: history and nutritional importance. Biol. Trace Elem. Res. 32, 3-8.

Mowat, D.N., Chang, X., Yang, W.Z., 1993. Chelated chromium for stressed feeder calves. Can. J. Anim. Sci. 73, 49-55.

National Research Council (NRC), 2001. Nutrient Requirements of Dairy Cattle. National Academy of Sciences, Washington, DC, USA

Perseghin, G., Caumo, A., Caloni, M., Testolin, G., Luzi, L., 2001. Incorporation of the fasting plasma FFA concentration into QUICKI improves its association with insulin sensibility in nonobese individuals. J. Clin. Endocrinol. Metab. 86, 4776-4781.

Pires, J.A.A., Souza, A.H., Grummer, R.R., 2007. Induction of hyperlipidemia by intravenous infusion of tallow emulsion causes insulin resistance in Holstein cows. J. Dairy Sci. 90, 2735-2744.

Rigout, S., Lemosquet, S., van Eys, J.E., Blum, J.W., 2002. Duodenal glucose increases glucose fluxes and lactose synthesis in grass silage-fed dairy cows. J. Dairy Sci. 85, 595-606.

Schoenberg, K.M., Overton, T.R., 2011. Effects of plane of nutrition and 2,4-thiazolidinedione on insulin responses and adipose tissue gene expression in dairy cattle during late gestation. J. Dairy Sci. 94, 6021-6035.

Shiang, K.D., 2004. The SAS Calculations of Areas Under the Curve (AUC) for Multiple Metabolic Readings. Available at: 〈http://www.lexjansen.com/wuss/2004/ posters/c_post_the_sas_calculations_.pdf (accessed 01.06.14).

Sinclair, K.D., 2010. Declining fertility, insulin resistance and fatty acid metabolism in dairy cows: Developmental consequences for the oocyte and pre-implantation embryo. Acta Sci. Vet. 38, s545-s557.

Soltan, M.A., 2010. Effect of dietary chromium supplementation on productive and reproductive performance of early lactating dairy cows under heat stress. J. Anim. Physiol. Anim. Nutr. 94, 264-272.

Soto, P., Natzke, R.P., Hansen, P.J., 2003. Identification of possible mediators of embryonic mortality caused by mastitis: actions of lipopolysaccharide, prostaglandin F2 $\alpha$, and the nitric oxide generator, sodium nitroprusside dehydrate, on oocyte maturation and embryonic development in cattle. Am. J. Reprod. Immunol. 50, 263-272.

Stengärde, L., Holtenius, K., Tråvén, M., Hultgren, J., Niskanen, R., Emanuelson, U., 2010. Blood profiles in dairy cows with displaced abomasum. J. Dairy Sci. 93, 4691-4699.

Subiyatno, A., Mowat, D.N., Yang, W.Z., 1996. Metabolite and hormonal responses to glucose or propionate infusions in periparturient dairy cows supplemented with chromium. J. Dairy Sci. 79, 1436-1445.

Sumner, J.M., Valdez, F., McNamara, J.P., 2007. Effects of chromium propionate on response to an intravenous glucose tolerance test in growing Holstein heifers. J. Dairy Sci. 90, 3467-3474.

Van Saun, R.J., Sniffen, C.J., 1996. Nutritional management of the pregnant dairy cow to optimize health, lactation and reproductive performance. Anim. Feed Technol. Sci. 59, 13-26.

Vincent, J.B., 2001. The bio-inorganic chemistry of chromium (III). Polyhedron 20, $1-26$.

Wellen, K.E., Hotamisligil, G.S., 2005. Inflammation, stress, and diabetes. J. Clin. Investig. 115, 1111-1119.

West, J.W., Bondari, K., Johnson Jr, J.C., 1990. Effects of bovine somatotropin on milk yield and composition, body weight and condition score of Holstein and jersey cows. J. Dairy Sci. 73, 1062-1068.

Wildman, E.E., Jones, G.M., Wagner, P.E., Boman, R.L., Troutt, H.F., Lesch, T.N., 1982. A dairy cow body condition scoring system and its relationship to selected production characteristics. J. Dairy Sci. 65, 495-501. 